Braz J Med Biol Res, September 2012, Volume 45(9) 811-817

doi: 10.1590/S0100-879X2012007500099

Relationship of $I L-1$ and $T N F-\alpha$ polymorphisms with Helicobacter pylori in gastric diseases in a Brazilian population

J.C. Santos, M.S.P. Ladeira, J. Pedrazzoli Jr. and M.L. Ribeiro

The Brazilian Journal of Medical and Biological Research is partially financed by

\section{且CNPq}

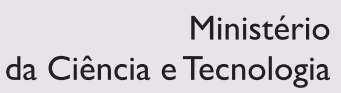

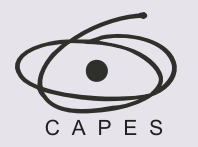

Ministério da Educação
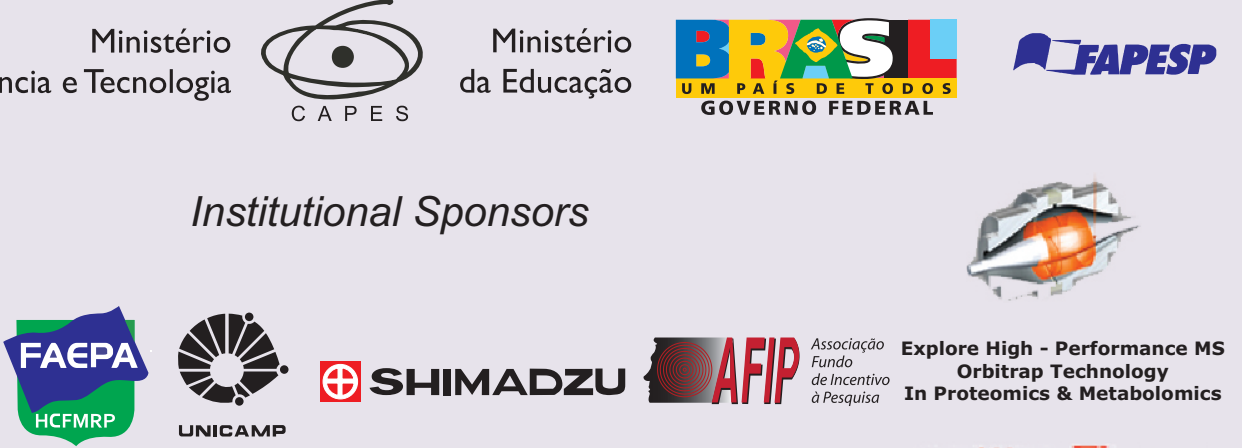

Institutional Sponsors

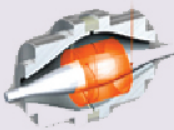

$\oplus$ SHIMADZU UNICAMP

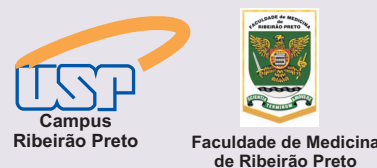
de Ribeirão Preto 


\title{
Relationship of IL-1 and TNF- $\alpha$ polymorphisms with Helicobacter pylori in gastric diseases in a Brazilian population
}

\author{
J.C. Santos ${ }^{1}$, M.S.P. Ladeira ${ }^{2}$, J. Pedrazzoli Jr. ${ }^{1}$ and M.L. Ribeiro ${ }^{1}$ \\ 1 Unidade Integrada de Farmacologia e Gastroenterologia, Universidade São Francisco, \\ Bragança Paulista, SP, Brasil \\ 2Departamento de Patologia, Universidade Estadual Paulista, Botucatu, SP, Brasil
}

\begin{abstract}
It is well known that the risk of development of gastric cancer (GC) in Helicobacter pylori-infected patients depends on several factors. Thus, the aim of this study was to investigate the effect of proinflammatory cytokine gene polymorphisms for $I L-1 \beta$, IL-1RN and TNF- $\alpha$ on the development of GC in a Brazilian population. A total of 202 biopsies obtained from Brazilian patients with chronic gastritis and GC were included in the study. Infection with $H$. pylori cagA ${ }^{+}$was determined by the polymerase chain reaction (PCR) as previously described. IL-1 $\beta, I L-1 R N$ and $T N F-\alpha$ polymorphism genotyping was performed by restriction fragment length polymorphism PCR. Associations between gene polymorphisms, clinical diseases and virulence markers were evaluated using either the $x^{2}$ test or the Fisher exact test. Our results demonstrated that the $/ L-1 \beta-511 \mathrm{C} / \mathrm{C}$ and $I L-1 \beta-511 \mathrm{C} / \mathrm{T}$ alleles were associated with chronic gastritis in $H$. pylori-positive patients $(P=0.04$ and $P=0.05$, respectively) and the $I L-1 \beta$ $-511 \mathrm{C} / \mathrm{C}$ genotype was associated with $\mathrm{GC}(\mathrm{P}=0.03)$. The frequency of $I L-1 R N$ alleles from patients with chronic gastritis and GC indicated that there was no difference between the genotypes of the groups studied. Similar results were found for TNF- $\alpha$ -308 gene polymorphisms. Our results indicate that the $/ L-1 \beta-511 \mathrm{C} / \mathrm{C}$ and $\mathrm{C} / \mathrm{T}$ gene polymorphisms are associated with chronic gastritis and GC development in H. pylori-infected individuals.
\end{abstract}

Key words: Chronic gastritis; Gastric cancer; Polymorphisms; Helicobacter pylori; Interleukins; IL-1 $\beta$; IL-1RN; TNF- $\alpha$

\section{Introduction}

Infection with Helicobacter pylori is a major risk factor for gastric cancer (GC), which is the second leading cause of cancer death worldwide (WHO). This Gram-negative bacterium is a well-established etiologic factor and has been classified as a type 1 carcinogen because of its causative role in the development of GC (1). Gastric carcinogenesis is a complex process resulting from the interaction between genetic and environmental factors (2). It is known that diet, smoking, alcohol consumption, and low intake of fruits and vegetables can be implicated in disease development (3). The presence of $H$. pylori is responsible for triggering a pathological progression in the gastric mucosa that begins with chronic gastritis and progresses to atrophic gastritis, intestinal metaplasia, dysplasia, and eventually GC (4).

Some bacterial factors are correlated with the severity of disease. However, bacterial factors alone are not sufficient to explain the diverse outcomes of $H$. pylori-related diseases
(5-7). The cytotoxin-associated gene (cagA) was the first strainspecific gene identified in $\mathrm{H}$. pylori that was considered to be a marker for the presence of a pathogenicity island (cag-PAI) (8). Infection with cag-PAl-bearing $H$. pylori has been recognized as increasing risk for the development of several gastric disorders, such as peptic ulceration, GC and mucosa-associated lymphoid tissue lymphoma (9).

The immune response of the host is considered to be a key event in the development of GC. This reaction is induced by the contact of $H$. pylori with gastric cells and is followed by the stimulation of proinflammatory cytokine production (10). Additionally, several studies have reported a relationship between $H$. pylori infection and an increase in the inflammatory gene response characterized by the up-regulation of several genes such as $I L-1 \beta, I L-1 R N, I L-8, I L-10$, and tumor necrosis factor-alpha $(T N F-\alpha)$. These cytokines are considered to be important mediators of gastric pathophysiology and could play

Correspondence: M.L. Ribeiro, Unidade Integrada de Farmacologia e Gastroenterologia, Universidade São Francisco, Av. São Francisco de Assis, 218, 12916-900 Bragança Paulista, SP, Brasil. Fax: +55-11-4034-1825. E-mail: marcelo.ribeiro@saofrancisco.edu.br

Received January 18, 2012. Accepted May 29, 2012. Available online June 22, 2012. Published August 17, 2012. 
a critical role in the etiology of GC $(1,11)$.

$\mathrm{IL}-1 \beta$ is a proinflammatory cytokine induced by $H$. pylori infection and is a powerful inhibitor of gastric acid secretion. Its effects promote hypochlorhydria, favoring further colonization of $H$. pylori and more severe gastritis (12). It has been shown that $I L-1 \beta-31$ and $I L-1 \beta-511$ polymorphisms are associated with increased production of $I L-1 \beta$ and are therefore related to the development of $G C$ (13-15). Thus, persons harboring $I L-1 \beta$ polymorphisms who are also colonized by an $H$. pyloritoxigenic strain have an increased risk of developing GC (15).

Another cytokine that has an important influence on IL-1 $\beta$ levels is IL-1ra, the gene $(I L-1 R N)$ of which is also known to be polymorphic. The IL-1RNgene has a penta-allelic 86-bp tandem repeat polymorphism in intron 2 . The rare variant $I L-1 R N^{\star} 2$ has been associated with GC (13). Furthermore, it is known that gastrin is up-regulated by $H$. pylori infection. However, acid secretion from parietal cells is inhibited mainly due to the proinflammatory cytokines IL-1 $\beta$ and TNF- $\alpha$ (16).

TNF- $\alpha$ has an important role in host defense against $H$. pylori infection, but a high concentration of this cytokine may cause severe pathology. TNF- $\alpha$ production is regulated in part at the transcriptional level, and many studies have implicated TNF- $\alpha$ polymorphisms as potential determinants of disease susceptibility (17).

The risk of development of GC in H. pylori-infected patients depends on several factors. Genotyping of bacterium and host gene polymorphisms could be important in the early identification of individuals at high risk to develop severe gastric diseases. Therefore, the aim of the present study was to evaluate the effect of proinflammatory cytokine gene polymorphisms in IL$1 \beta, I L-1 R N$, and $T N F-\alpha$ in the Brazilian population.

\section{Patients and Methods}

\section{Patients}

The study was approved by the Ethics Committees of Faculdade de Medicina, Universidade Estadual Paulista (UNESP), Botucatu, SP, Brazil, and of Universidade São Francisco, Braganca Paulista, $\mathrm{SP}$, Brazil, as well as by the National Committee of Ethics in Research, Brasília, DF, Brazil. Informed consent to participate was obtained from all patients or their guardians.

We studied 202 volunteer patients of both genders with gastric disease. Mean patient age was $59.2 \pm 11.36$ years (range: $19-87$ years). Exclusion criteria were as follows: previous gastroduodenal surgery, prior treatment with antimicrobial therapy to eradicate the

$F=$ forward $R$ = reverse microorganism, use of NSAIDs and/or proton pump inhibitors in the last three months, and being a smoker, alcoholic, drug user, or user of therapeutic drugs in the last 30 days.

\section{Biopsy collections}

Biopsies of patients with gastric complaints were obtained during endoscopy from the lesser curvature of the antrum (the distal region of the stomach) within $2 \mathrm{~cm}$ of the pyloric ring. Biopsies from GC were obtained during gastric surgery to remove gastric carcinoma. One biopsy from each site was used for a rapid urease test. Two biopsies were used for histopathological evaluation. One sample was used for bacterial genotyping by the polymerase chain reaction (PCR). $H$. pylori infection was confirmed when positive results were obtained in at least two of the following tests: rapid urease test, histological analysis and gastric biopsy PCR.

\section{Histopathology}

Tissue from the gastric mucosa was fixed in 10\% formalin for $24 \mathrm{~h}$, dehydrated in alcohol and xylene and embedded in paraffin. Sequential 3-5- $\mu \mathrm{m}$ sections were cut and stained with hematoxylin-eosin for routine histology. Gastritis was classified according to Sydney's system (18), and the presence of $H$. pylori was confirmed in carbolfuchsin-stained sections.

\section{DNA extraction and $\boldsymbol{H}$. pylori genotyping}

To determine the presence of $H$. pylori, we used the rapid urease test (Probac, Brazil), histology, and PCR. The bacterium was considered to be present if two or more methods were positive.

A biopsy of the antrum of each patient was used for extraction of genomic DNA. DNA isolation was performed according to the phenol-chloroform protocol adapted by Fox et al. (19).

All primers (Invitrogen ${ }^{\mathrm{TM}}$ Life Technologies, USA) used in this study are presented in Table 1. PCR assays are

Table 1. Specific primers used for polymorphism analyses.

\begin{tabular}{|c|c|c|c|c|}
\hline Gene & Primer & Sequence $\left(5^{\prime} \rightarrow 3^{\prime}\right)$ & PCR (bp) & References \\
\hline \multirow[t]{2}{*}{$I L-1 \beta-511$} & $\mathrm{~F}$ & TCCTCAGAGGCTCCTGCAAT & 304 & 14 \\
\hline & $\mathrm{R}$ & TGTGGGTCTCTACCTTGGGTG & & \\
\hline \multirow[t]{2}{*}{$T N F-\alpha-308$} & $\mathrm{~F}$ & CCCCAAAAGAAATGGAGGC & 107 & 14 \\
\hline & $\mathrm{R}$ & TCTTCTGGGCCACTGACTGAT & & \\
\hline \multirow[t]{2}{*}{$I L-1 R N$} & $\mathrm{~F}$ & ССССТCAGCAACACTCC & $240-595$ & 13 \\
\hline & $\mathrm{R}$ & GGTCAGAAGGGCAGAGA & & \\
\hline \multirow[t]{2}{*}{$S S A$} & $\mathrm{~F}$ & TGGCGTGTCTATTGACAGCGAGC & 300 & 20 \\
\hline & $\mathrm{R}$ & CCTGCTGGGCATACTTCACCATG & & \\
\hline \multirow[t]{2}{*}{ glmM } & $\mathrm{F}$ & AAGCTTTTAGGGGTGTTAGGGGTTT & 294 & 21 \\
\hline & $\mathrm{R}$ & AAGCTTACTTTCTAACACTAACGC & & \\
\hline \multirow[t]{2}{*}{$\operatorname{cagA}$} & D008 & TTAGAATAATCAACAAACATCACGCCAT & 297 & 22 \\
\hline & R008 & TTAGAATAATCAACAAACATCACGCCAT & & \\
\hline
\end{tabular}


performed in a total volume of $50 \mu \mathrm{L}$, containing $50 \mathrm{pmol}$ primer, 100 ng genomic DNA, 1.0 mM of each dNTP (Invitrogen $^{\mathrm{TM}}$ Life Technologies) and 2.5 U Taq DNA polymerase (Invitrogen ${ }^{\mathrm{TM}}$ Life Technologies). The reaction mixtures were cycled in an automated GeneAmp ${ }^{\circledR}$ PCR System 9700 thermal cycler (PE Applied Biosystems, USA). PCR was performed using the following conditions: initial denaturation at $95^{\circ} \mathrm{C}$ for $3 \mathrm{~min}$ followed by 35 cycles of denaturation at $95^{\circ} \mathrm{C}$ for $1 \mathrm{~min}$, annealing ranging from $45^{\circ} \mathrm{C}$ to $60^{\circ} \mathrm{C}$ for 1 min and extension at $72^{\circ} \mathrm{C}$ for $1 \mathrm{~min}$. The final cycle included a 7-min extension step to ensure full extension of the PCR products. The presence of $H$. pylori was confirmed by PCR of the SSA (20) and g/mM (21) genes. The cagA gene was analyzed using the primers D008 and R008 described by Covacci et al. (22).

\section{Analysis of polymorphisms}

The analysis of the polymorphisms IL-1 $\beta$ (-511 C/T - rs16944), TNF- $\alpha$ (-308 G/A - rs1800629) and intron 2 VNTR of the IL-1RN were analyzed by PCR in a $50-\mu \mathrm{L}$ total reaction volume. The reaction mixture contained the following reagents: $2.5 \mu \mathrm{L}$ genomic DNA, $20 \mu \mathrm{mol}$ of each primer, $0.2 \mathrm{mM}$ of each dNTP (dATP, dCTP, dGTP, dTTP), $1.5 \% \mathrm{MgCl}_{2}, 2.5 \mathrm{U}$ Platinum ${ }^{\circledR}$ Taq DNA polymerase and enzyme reaction buffer.

Genotyping of the $I L-1 \beta-511$ T>C SNP was performed by restriction fragment length polymorphism PCR (RFLP-PCR) as previously described. PCR products were digested with Aval (New England Biolabs, USA) at $37^{\circ} \mathrm{C}$ for $2 \mathrm{~h}$ and then analyzed on $2 \%$ agarose gels. Individuals with the genotype $I L-1 \beta-511 \mathrm{C} / \mathrm{C}$ produced digested DNA bands of 190/104 bp. Individuals with the $I L-1 \beta-511 \mathrm{~T} / \mathrm{T}$ genotype had no amplicon digestion and generated only one band of $304 \mathrm{bp}$. A heterozygous genotype of IL-1 $\beta-511$ C/T produced 304/190/104-bp bands.

The TNF- $\alpha$ polymorphism (-308 G/A) creates a restriction site for $\mathrm{Ncol}$ (C $\downarrow$ CATGG). The amplicon of $107 \mathrm{bp}$ was digested with the restriction enzyme $\mathrm{Ncol}$ (New England Biolabs) at $37^{\circ} \mathrm{C}$ for $2 \mathrm{~h}$ and analyzed on $2 \%$ agarose 1000 (Invitrogen) gels. The TNF- $\alpha$ -308 G/G genotype produced 87/20-bp bands after amplicon digestion. Individuals with the TNF- $\alpha-308$ A/A genotype did not have amplicon digestion and generated only one band of $107 \mathrm{bp}$. The heterozygous TNF- $\alpha-308 \mathrm{G} / \mathrm{A}$ genotype produced three bands 107/87/20 bp in length.

The products generated by PCR of IL$1 R N$ were subjected to electrophoresis on $2 \%$ agarose gels and classified as follows: allele $1-4$ repeats $(410 \mathrm{bp})$; allele $2-2$ repeats $(240$ bp); allele 3-5 repeats (500 bp); allele 4-3 repeats (235 bp), and allele 5-6 repeats (595 bp) (13). All analyses were made in duplicate.

\section{Statistical analysis}

Associations between gene polymorphisms, clinical diseases and virulence markers were evaluated using the $\mathrm{X}^{2}$ test with Yates continuity correction. The statistical significance was assessed by ANOVA multiple comparisons using a $t$-test with post-test correction. Hardy-Weinberg equilibrium was tested among the groups. A P value of $<0.05$ was considered to be statistically significant. The SPSS software (version 11.5; SPSS Inc., USA) was used for data analysis.

\section{Results}

\section{Prevalence of $\boldsymbol{H}$. pylori infection and genotyping}

There were no differences in gender or age distribution between the study groups. H. pylori infection was analyzed in biopsy specimens from 202 patients who underwent endoscopy and was detected in $87 \%$ (176/202). Histopathological analysis showed that $13 \%(26 / 202)$ had normal mucosa and were uninfected, 55\% (112/202) had chronic gastritis, and $32 \%(64 / 202)$ had GC. All patients with GC were infected

Table 2. Frequency of the $I L-1 \beta, I L-1 R N$ and $T N F-\alpha$ polymorphisms.

\begin{tabular}{|c|c|c|c|}
\hline \multirow[t]{2}{*}{ Genotypes } & \multicolumn{2}{|c|}{ Chronic gastritis $(\mathrm{N}=138)$} & \multirow{2}{*}{$\begin{array}{l}\text { Cancer }(\mathrm{N}=64) \\
\text { H. } \text { pylori }^{+}(\mathrm{N}=64)\end{array}$} \\
\hline & H. pylori- $(\mathrm{N}=26)$ & H. pylori ${ }^{+}(\mathrm{N}=112)$ & \\
\hline \multicolumn{4}{|l|}{$I L-1 \beta-511$} \\
\hline $\mathrm{C} / \mathrm{C}$ & - & $28(25 \%)^{*}$ & $13(20 \%)^{*}$ \\
\hline $\mathrm{C} / \mathrm{T}$ & $20(77 \%)$ & $52(46 \%)^{*}$ & $35(55 \%)$ \\
\hline $\mathrm{T} / \mathrm{T}$ & $6(23 \%)$ & $32(29 \%)$ & $16(25 \%)$ \\
\hline${ }^{*} \mathrm{~T}$ & 0.61 & 0.51 & 0.52 \\
\hline 帥 values & - & $<0.001$ & 0.03 \\
\hline \multicolumn{4}{|l|}{$I L-1 R N$} \\
\hline $1 / 1$ & $7(27 \%)$ & $45(40 \%)$ & $20(31 \%)$ \\
\hline $1 / 2$ & $17(65 \%)$ & $57(51 \%)$ & $42(65 \%)$ \\
\hline $1 / 3,4$ & - & $2(2 \%)$ & - \\
\hline $2 / 2$ & $2(8 \%)$ & $6(5 \%)$ & $2(4 \%)$ \\
\hline${ }^{*} 2$ & 0.40 & 0.31 & 0.36 \\
\hline ‡P values & - & NS & NS \\
\hline \multicolumn{4}{|l|}{$T N F-\alpha-308$} \\
\hline G/G & $22(85 \%)$ & $78(70 \%)$ & $44(68 \%)$ \\
\hline $\mathrm{G} / \mathrm{A}$ & $4(15 \%)$ & $30(27 \%)$ & $20(32 \%)$ \\
\hline $\mathrm{A} / \mathrm{A}$ & - & $3(3 \%)$ & - \\
\hline${ }^{*} \mathrm{~A}$ & 0.07 & 0.16 & 0.16 \\
\hline$\ddagger \mathrm{P}$ values & - & NS & NS \\
\hline
\end{tabular}

NS $=$ not significant. ${ }^{*} \mathrm{P}<0.05$ for $H$. pylori ${ }^{-}$versus $H$. pylori ${ }^{+}$chronic gastritis and $H$. pylori ${ }^{+}$gastric cancer ( $\mathrm{X}^{2}$ test). $¥ \mathrm{P}$ values for ANOVA multiple comparisons using a $t$-test with post-test correction. 
with H. pylori. Of the $112 \mathrm{H}$. pylori-positive patients, $84(75 \%)$ were cagA-positive. There was a high prevalence of infection with cagA-positive strains among GC patients.

\section{IL-1 $\beta, I L-1 R N$ and TNF- $\alpha$ polymorphisms}

The genotype distribution in each group was tested using Hardy-Weinberg equilibrium (HWE). Regarding the IL-1 $\beta-511 \mathrm{C} / \mathrm{T}$ polymorphism, $\mathrm{P}$ values of 0.56 and 0.44 were found for chronic gastritis and cancer, respectively. For TNF- $\alpha-308, \mathrm{P}$ values of 0.95 and 0.13 were found for chronic gastritis and cancer, respectively. $I L-1 R N$ was not in HWE and was not evaluated.

The genotype frequencies of the polymorphisms studied are shown in Table 2. The frequency of the IL-1 $\beta-511 \mathrm{C} / \mathrm{T}$ polymorphism in patients with chronic gastritis differed significantly between the $H$. pyloripositive group (52/112) and the uninfected group $(20 / 26)(P=0.05)$. Similarly, a significant difference was found in the frequency of the $I L-1 \beta-511 \mathrm{C} / \mathrm{C}$ genotype in chronic gastritis and $G C$ patients $(P=$ 0.04 and $P=0.03$, respectively).

With respect to the frequency of the $I L-1 R N$ alleles from patients with chronic gastritis and GC, our data indicated that there was no difference in the genotypes from the groups studied. Similar results were found for the TNF- $\alpha-308$ gene polymorphisms.

\section{Correlation between polymorphisms and H. pylori cagA}

Table 3 shows the frequency of each polymorphism and the distribution of $\operatorname{cagA}^{+}$and $\operatorname{cagA}^{-}$samples from patients with chronic gastritis and GC. Regarding the $I L-$ $1 \beta-511$ polymorphism, we found an association between heterozygosity and cag $\mathrm{A}^{-}$in chronic gastritis patients $(\mathrm{P}=$ 0.02). An individual analysis of the genotype frequencies of IL-1RN*2 and TNF- $\alpha-308$ and the presence of cagA revealed a similar distribution among all groups.

\section{Discussion}

Distinct host cytokine responses to $H$. pylori-induced gastric mucosal inflammation appear to play a significant role in clinical outcome including the development of gastric diseases and GC. However, the relationship between gene host cytokine polymorphisms and the nature and severity of the clinical outcome has not been well characterized. Furthermore, the ethnic diversity of the Brazilian population is known to be an important factor that has been associated with variations in the frequency of several markers. In view of the need to characterize the allelic frequencies of gene host cytokine polymorphisms in mixed populations, the present study evaluated the effect of proinflammatory
Table 3. Frequency of the polymorphisms of $I L-1 \beta, I L-1 R N$ and $T N F-\alpha$ related to the presence or absence of virulence factor cagA.

\begin{tabular}{|c|c|c|c|}
\hline \multirow[t]{2}{*}{ Genotypes } & \multicolumn{2}{|c|}{ Chronic gastritis $(\mathrm{N}=112)$} & \multirow{2}{*}{$\begin{array}{l}\text { Cancer }(\mathrm{N}=64) \\
\operatorname{cagA}^{+}(\mathrm{N}=64)\end{array}$} \\
\hline & $\operatorname{cagA^{-}}(N=28)$ & $\operatorname{cag} \mathrm{A}^{+}(\mathrm{N}=84)$ & \\
\hline \multicolumn{4}{|l|}{$\mid L-1 \beta-511$} \\
\hline $\mathrm{C} / \mathrm{C}$ & $2(7 \%)$ & $22(27 \%)$ & $13(20 \%)$ \\
\hline $\mathrm{C} / \mathrm{T}$ & $20(71 \%)$ & $39(46 \%)$ & $35(55 \%)$ \\
\hline$T / T$ & $6(22 \%)$ & $23(27 \%)$ & $16(25 \%)$ \\
\hline${ }^{*} \mathrm{~T}$ & 0.57 & 0.50 & 0.52 \\
\hline ‡P values & - & NS & NS \\
\hline \multicolumn{4}{|l|}{ IL-1RN } \\
\hline $1 / 1$ & $7(25 \%)$ & $36(43 \%)$ & $20(31 \%)$ \\
\hline $1 / 2$ & $18(65 \%)$ & $43(51 \%)$ & $42(65 \%)$ \\
\hline $1 / 3,4$ & $1(3 \%)$ & $1(1 \%)$ & - \\
\hline $2 / 2$ & $2(7 \%)$ & $4(5 \%)$ & $2(4 \%)$ \\
\hline *2 & 0.39 & 0.30 & 0.36 \\
\hline 抽 values & - & NS & NS \\
\hline \multicolumn{4}{|l|}{$T N F-\alpha-308$} \\
\hline $\mathrm{G} / \mathrm{G}$ & $25(90 \%)$ & $60(72 \%)$ & $44(68 \%)$ \\
\hline $\mathrm{G} / \mathrm{A}$ & $3(10 \%)$ & $20(24 \%)$ & $20(32 \%)$ \\
\hline $\mathrm{A} / \mathrm{A}$ & - & $3(4 \%)$ & - \\
\hline${ }^{*} \mathrm{~A}$ & 0.05 & 0.15 & 0.16 \\
\hline ‡P values & - & NS & NS \\
\hline
\end{tabular}

‡P values for ANOVA multiple comparisons using a $t$-test with post-test correction. NS = not significant.

cytokine gene polymorphisms in $I L-1 \beta, I L-1 R N$, and $T N F-\alpha$ in patients with chronic gastritis and GC.

Infection with this chronic and active bacterium will inevitably cause an inflammatory response in the host. Histologically, the host response to this bacterium is characterized by infiltration of lymphocytes, macrophages and neutrophils in the gastric mucosa. This reaction is most likely induced by the contact of $H$. pylori with the gastric cells and is followed by the stimulation of proinflammatory cytokine production (10).

In addition to their role in $H$. pylori infections, gene polymorphisms play an important role in GC development $(16,23)$. Currently, there are approximately 1400 publications in PubMed covering more than 100 different genes with polymorphisms linked to GC. The most comprehensive knowledge exists for cytokine-encoding genes, which account for roughly one quarter of these publications. Within this subset of publications, the $I L-1 \beta$ gene locus is the focus of more than 200 studies and represents a major target for research on gastric carcinogenesis (24).

$I L-1 \beta$ is an important factor for initiating and amplifying the inflammatory response. It acts as a potent inhibitor of acid secretion and its expression levels are increased in $\mathrm{H}$. pylori-infected patients $(25,26)$. Some investigators have 
shown that $I L-1 \beta-511$ polymorphisms are associated with increased $I L-1 \beta$ production and are therefore related to the development of GC (15).

In the present study, we found an association between the IL-1 $\beta-511 \mathrm{CT} / \mathrm{CC}$ genotypes and the presence of chronic gastritis and GC in patients infected with $H$. pylori. These results are similar to those of previous studies conducted on Mexican patients (27). It has also been reported that the IL-1 $\beta-511$ CC/CT genotypes potentiate cytokine production and are significantly associated with the clinical development of $H$. pylori infection $(27,28)$. Additionally, a greater risk of chronic gastritis and GC development has also been reported in the Japanese population harboring the $I L-1 \beta-511 C C$ genotype and in the Chinese population with the CT genotype. Furthermore, within the Thai population, the $I L-1 \beta-511$ CC genotype is considered to be a risk factor for GC development (29). Conversely, some studies have yielded conflicting results. A recent meta-analysis showed a positive association between the $T$ allele at the IL-1 $\beta$-511 position and GC development in Caucasians but not in Asians (12). Similar results indicate that there is no association in Italian (30), Jamaican (31), or Brazilian populations $(32,33)$.

The IL-1RN polymorphisms are closely associated with the regulation of IL-1 $\beta$ activity and are related to GC development $(12,13)$. It has been proposed that individuals with the $I L-1 R N^{*} 2$ genotype have elevated levels of circulating IL-1 $\beta$. The increased IL-1 $\beta$ levels result in a prolonged inflammatory response and increase the risk of disease development. However, our data indicate that there was no association between IL-1RN genotypes and the subgroups studied. Similar results were reported in a meta-analysis by Camargo et al. (12). Although the results presented here and those observed by other investigators (33) did not indicate an association between the IL-1RN*2 allele and the development of GC, other studies conducted in Brazil have shown that this allele is associated with the development of GC in different Brazilian populations $(32,34)$. Such results could be attributed to the miscegenation of the Brazilian population because some studies indicate that the frequencies of these markers usually show large ethnic variations (35). Additionally, in a meta-analysis, Kamangar et al. (36) reported no association between the genotypes of $I L-1 \beta-511$ or IL-1RN and GC development.

In addition to the previously described polymorphisms, several investigators have reported that changes in the promoter region of $T N F-\alpha$ are related to an increased risk of GC development (37). Regarding the TNF- $\alpha-308 \mathrm{G} / \mathrm{A}$ polymorphisms, our data indicate that there was no difference between subgroups. The data presented here are similar to those reported by Melo Barbosa et al. (32) in a Brazilian population and by Gorouhi et al. (37) in a metaanalysis and are equivalent to the frequencies detected in Caucasians, Asians and Hispanics. Additionally, these authors did not detect any association between TNF- $\alpha-308$ GG or GAgenotypes and the development of GC. Moreover, these authors found that genotype A/A was associated with a moderately increased risk of developing GC. The data presented here revealed no association between the genotypes of $T N F-\alpha-308$ and the development of GC. This discrepancy could easily be attributed to the heterogeneity of the Brazilian population.

Infection by cagA-positive $H$. pylori strains has been associated with several clinical outcomes. Epidemiological studies have associated the presence of the cagA gene with the development of several gastric diseases and GC (38) and with cellular proliferation (39). Our study showed that patients with chronic gastritis infected by cagA-positive $H$. pylori had the highest cytokine mRNA and protein levels (40). However, our data did not reveal an association between the presence of any polymorphism and infection with cagA-positive strains. Other studies have reported an association between $H$. pylori cagA-positive strains and the polymorphisms in patients with gastritis and GC in Brazil (32) and in Portugal (15). Our data indicate that there was no preferential colonization of specific hosts by specific bacterial strains. The association of polymorphisms with certain bacterial strain types indicated that host-specific colonization or adaptation occurs, which may explain the heterogeneity of $H$. pylori strains in different populations. The Brazilian population is composed of a genetic mix of various ethnic groups, including Portuguese, Africans and Amerindians. Thus, the heterogeneity between the allele frequencies of the polymorphisms studied in our population compared with those of other ethnic groups is a product of the miscegenation of the Brazilian population.

Our results indicated that in the Brazilian population the $I L-1 \beta-511$ CC and CT gene polymorphisms were associated with chronic gastritis and GC development in $H$. pylori-infected individuals. No correlation between IL-1RN and $T N F-\alpha$ gene polymorphisms was observed in any gastric disease. More extensive studies investigating a broader range of polymorphisms, as well as other pro- and anti-inflammatory genes, are required to conclusively assess the impact of gene polymorphisms on gastric mucosal cytokine production.

\section{Acknowledgments}

Research supported by FAPESP (\#2005/56736-9). 


\section{References}

1. Persson C, Canedo P, Machado JC, El-Omar EM, Forman D. Polymorphisms in inflammatory response genes and their association with gastric cancer: A HuGE systematic review and meta-analyses. Am J Epidemiol 2011; 173: 259-270.

2. Gonzalez CA, Sala N, Capella G. Genetic susceptibility and gastric cancer risk. Int J Cancer 2002; 100: 249-260.

3. Kelley JR, Duggan JM. Gastric cancer epidemiology and risk factors. J Clin Epidemiol 2003; 56: 1-9.

4. Correa P. Human gastric carcinogenesis: a multistep and multifactorial process - First American Cancer Society Award Lecture on Cancer Epidemiology and Prevention. Cancer Res 1992; 52: 6735-6740.

5. Furuta T, El-Omar EM, Xiao F, Shirai N, Takashima M, Sugimura $\mathrm{H}$. Interleukin 1 beta polymorphisms increase risk of hypochlorhydria and atrophic gastritis and reduce risk of duodenal ulcer recurrence in Japan. Gastroenterology 2002; 123: 92-105

6. Hansson LE, Nyren O, Hsing AW, Bergstrom R, Josefsson $\mathrm{S}$, Chow $\mathrm{WH}$, et al. The risk of stomach cancer in patients with gastric or duodenal ulcer disease. N Engl J Med 1996; 335: 242-249.

7. Broutet N, Moran A, Hynes S, Sakarovitch C, Megraud F. Lewis antigen expression and other pathogenic factors in the presence of atrophic chronic gastritis in a European population. J Infect Dis 2002; 185: 503-512.

8. Censini S, Lange C, Xiang Z, Crabtree JE, Ghiara P, Borodovsky $\mathrm{M}$, et al. cag, a pathogenicity island of Helicobacter pylori, encodes type I-specific and disease-associated virulence factors. Proc Natl Acad Sci U S A 1996; 93: 1464814653.

9. Tiwari SK, Sharma V, Sharma VK, Gopi M, Saikant R, Nandan A, et al. Phylogenetic analysis, based on EPIYA repeats in the cagA gene of Indian Helicobacter pylori, and the implications of sequence variation in tyrosine phosphorylation motifs on determining the clinical outcome. Genet Mol Biol 2011; 34: 280-285.

10. Israel DA, Peek RM. Pathogenesis of Helicobacter pyloriinduced gastric inflammation. Aliment Pharmacol Ther 2001; 15: $1271-1290$.

11. Tu S, Bhagat G, Cui G, Takaishi S, Kurt-Jones EA, Rickman $B$, et al. Overexpression of interleukin-1 beta induces gastric inflammation and cancer and mobilizes myeloid-derived suppressor cells in mice. Cancer Cell 2008; 14: 408-419.

12. Camargo MC, Mera R, Correa P, Peek RM Jr, Fontham $\mathrm{ET}$, Goodman KJ, et al. Interleukin-1beta and interleukin-1 receptor antagonist gene polymorphisms and gastric cancer: a meta-analysis. Cancer Epidemiol Biomarkers Prev 2006; 15: 1674-1687.

13. El-Omar EM, Oien K, Murray LS, El-Nujumi A, Wirz A, Gillen $D$, et al. Increased prevalence of precancerous changes in relatives of gastric cancer patients: critical role of $H$. pylori. Gastroenterology 2000; 118: 22-30.

14. El-Omar EM, Rabkin CS, Gammon MD, Vaughan TL, Risch $H A$, Schoenberg JB, et al. Increased risk of noncardia gastric cancer associated with proinflammatory cytokine gene polymorphisms. Gastroenterology 2003; 124: 1193-1201.

15. Figueiredo C, Machado JC, Pharoah P, Seruca R, Sousa $\mathrm{S}$, Carvalho R, et al. Helicobacter pylori and interleukin 1 genotyping: an opportunity to identify high-risk individuals for gastric carcinoma. J Natl Cancer Inst 2002; 94: 16801687.

16. Peek RM Jr, Crabtree JE. Helicobacter infection and gastric neoplasia. J Pathol 2006; 208: 233-248.

17. Yea SS, Yang YI, Jang WH, Lee YJ, Bae HS, Paik KH. Association between TNF-alpha promoter polymorphism and Helicobacter pylori cagA subtype infection. J Clin Pathol 2001; 54: 703-706.

18. Dixon MF, Genta RM, Yardley JH, Correa P. Classification and grading of gastritis. The updated Sydney System. International Workshop on the Histopathology of Gastritis, Houston 1994. Am J Surg Pathol 1996; 20: 1161-1181.

19. Fox JG, Dewhirst FE, Fraser GJ, Paster BJ, Shames B, Murphy JC. Intracellular Campylobacter-like organism from ferrets and hamsters with proliferative bowel disease is a Desulfovibrio sp. J Clin Microbiol 1994; 32: 1229-1237.

20. Mikula M, Dzwonek A, Jagusztyn-Krynicka K, Ostrowski J. Quantitative detection for low levels of Helicobacter pylori infection in experimentally infected mice by real-time PCR. J Microbiol Methods 2003; 55: 351-359.

21. Bickley J, Owen RJ, Fraser AG, Pounder RE. Evaluation of the polymerase chain reaction for detecting the urease $C$ gene of Helicobacter pylori in gastric biopsy samples and dental plaque. J Med Microbiol 1993; 39: 338-344.

22. Covacci A, Censini S, Bugnoli M, Petracca R, Burroni D, Macchia G, et al. Molecular characterization of the 128-kDa immunodominant antigen of Helicobacter pylori associated with cytotoxicity and duodenal ulcer. Proc Natl Acad Sci U S A 1993; 90: 5791-5795.

23. Gologan A, Graham DY, Sepulveda AR. Molecular markers in Helicobacter pylori-associated gastric carcinogenesis. Clin Lab Med 2005; 25: 197-222.

24. Wex T, Bornschein J, Malfertheiner P. Host polymorphisms of immune regulatory genes as risk factors for gastric cancer. Minerva Gastroenterol Dietol 2009; 55: 395-408.

25. Basso D, Scrigner M, Toma A, Navaglia F, Di Mario F, Rugge $\mathrm{M}$, et al. Helicobacter pylori infection enhances mucosal interleukin-1 beta, interleukin-6, and the soluble receptor of interleukin-2. Int J Clin Lab Res 1996; 26: 207-210.

26. Jung HC, Kim JM, Song IS, Kim CY. Increased motility of Helicobacter pylori by methylcellulose could upregulate the expression of proinflammatory cytokines in human gastric epithelial cells. Scand J Clin Lab Invest 1997; 57: 263-270.

27. Martinez-Carrillo DN, Garza-Gonzalez E, BetancourtLinares R, Monico-Manzano T, Antunez-Rivera C, RomanRoman A, et al. Association of IL1B -511C/-31T haplotype and Helicobacter pylori vacA genotypes with gastric ulcer and chronic gastritis. BMC Gastroenterol 2010; 10: 126.

28. Takagi A, Deguchi R, Kobayashi K, Miwa T. Cytokine expressions and $H$. pylori-associated gastric mucosal lesion. Keio J Med 2002; 51 (Suppl 2): 51-52.

29. Yamada S, Matsuhisa T, Makonkawkeyoon L, Chaidatch S, Kato S, Matsukura N. Helicobacter pylori infection in combination with the serum pepsinogen I/II ratio and interleukin1 beta-511 polymorphisms are independent risk factors for gastric cancer in Thais. J Gastroenterol 2006; 41: 11691177.

30. Zambon CF, Basso D, Navaglia F, Belluco C, Falda A, Fogar $P$, et al. Pro- and anti-inflammatory cytokines gene poly- 
morphisms and Helicobacter pylori infection: interactions influence outcome. Cytokine 2005; 29: 141-152.

31. Tseng FC, Brown EE, Maiese EM, Yeager M, Welch R, Gold BD, et al. Polymorphisms in cytokine genes and risk of Helicobacter pylori infection among Jamaican children. Helicobacter 2006; 11: 425-430.

32. Melo Barbosa HP, Martins LC, Dos Santos SE, Demachki $\mathrm{S}$, Assumpção MB, Aragão CD, et al. Interleukin-1 and TNFalpha polymorphisms and Helicobacter pylori in a Brazilian Amazon population. World J Gastroenterol 2009; 15: 14651471.

33. Gatti LL, Burbano RR, de Assumpção PP, Smith MA, Payão SL. Interleukin-1beta polymorphisms, Helicobacter pylori infection in individuals from Northern Brazil with gastric adenocarcinoma. Clin Exp Med 2004; 4: 93-98.

34. Oliveira JG, Duarte MC, Silva AE. IL-1 ra anti-inflammatory cytokine polymorphism is associated with risk of gastric cancer and chronic gastritis in a Brazilian population, but the TNF-beta pro-inflammatory cytokine is not. Mol Biol Rep 2012 (in press).

35. Ioannidis JP, Ntzani EE, Trikalinos TA. 'Racial' differences in genetic effects for complex diseases. Nat Genet 2004; 36:
$1312-1318$

36. Kamangar F, Cheng C, Abnet CC, Rabkin CS. Interleukin-1B polymorphisms and gastric cancer risk - a meta-analysis. Cancer Epidemiol Biomarkers Prev 2006; 15: 1920-1928.

37. Gorouhi F, Islami F, Bahrami H, Kamangar F. Tumournecrosis factor-A polymorphisms and gastric cancer risk: a meta-analysis. Br J Cancer 2008; 98: 1443-1451.

38. Blaser MJ, Perez-Perez GI, Kleanthous H, Cover TL, Peek $\mathrm{RM}$, Chyou $\mathrm{PH}$, et al. Infection with Helicobacter pylori strains possessing cagA is associated with an increased risk of developing adenocarcinoma of the stomach. Cancer Res 1995; 55: 2111-2115.

39. Peek RM Jr, Moss SF, Tham KT, Perez-Perez GI, Wang S, Miller GG, et al. Helicobacter pylori cagA+ strains and dissociation of gastric epithelial cell proliferation from apoptosis. J Natl Cancer Inst 1997; 89: 863-868.

40. Bartchewsky W Jr, Martini MR, Masiero M, Squassoni AC, Alvarez MC, Ladeira MS, et al. Effect of Helicobacter pylori infection on IL-8, IL-1 beta and COX-2 expression in patients with chronic gastritis and gastric cancer. Scand J Gastroenterol 2009; 44: 153-161. 